\title{
PREPARATION AND EVALUATION OF DIBIS FROM DIFFERENT VARIETIES OF GRAPE
}

\author{
AMER, REDA A. ${ }^{1}$ and AZZA K.ABD EL-HAMEED ${ }^{2}$
}

1. Hort. Crop processing Res. Department, Food Technology Research Institute, $A R C$, Alex, Egypt.

2. Horti. Crop processing Res. Department, Food Technology Research Institute, $A R C$, Giza, Egypt.

(Manuscript received 29 August 2016)

\begin{abstract}
$\mathrm{T}$ his study was carried out to produce grape dibis (a concentrated grape juice) as a natural source of sugar and bioactive compounds from three grope varieties namely Thompson seedless, Flame seedless and Roumy Ahmer (red). The Physicochemical properties and minerals content of grape juice and dibis were determined. Fractionation and identification of free sugar content, phenolic and flavonoids compounds, vitamin $\mathrm{C}$ and vitamin B complex of grape juice and dibis were determined by HPLC, and then sensory evaluations of grape dibis was carried out. The total soluble solids of dibis ranged from 70 to $73 \%$. Glucose and fructose were the major sugars in different grape juice and dibis from different varieties. All grape dibis were rich in vitamins (B1, B2, B3, B6 and B9). The organoleptic properties of dibis from the three varieties of grape showed that they were highly accepted by the panelists.
\end{abstract}

Keywords: grape juice, dibis; Phenolic compounds, Flavonoids, sugars, vitamin (C, B) , Sensory evaluation

\section{INTRODUCTION}

Grape (Vitis vinifera) is one of the world's largest fruit crops with an annual production of more than 60 million metric tons, and $80 \%$ of this production is used in wine production (FAOSTAT, 2007). It is consumed as fresh or processed into raisin, juice, wines and other products, Muslim countries mostly consume grapes as table grapes, grape pekmez (the Turkish name of concentrated grape juice) or raisin, whereas in European Mediterranean and North America, the main use of grapes is in wine production (Saito et al., 1998) . Grape juice consists of mainly water (81-86\%), with a high concentration of the sugars glucose and fructose. It has a high acidity due to the presence of tartaric, malic and citric acids. These acids cause a low pH value, guaranteeing balance between acidic and sweet tastes. About its mineral elements, a high potassium value and low sodium value are established (Iyer et al., 2010). Grapes are rich in antioxidants such as anthocyanins, flavones and tannins. It is these antioxidants that scientists believe are responsible for protecting the body against many forms of cancer. Red grapes in particular contain a compound called resveratrol 
which has been demonstrated to reduce cholesterol and protect the heart ( Mato et al., 2005).

Pekmez is one of the most common names of a concentrated and a shelf-life extended form of grape juice produced by boiling without the addition of sugar or other food additives. Therefore, it can be assumed to be a natural food containing natural sugars such as glucose, fructose and minerals. Pekmez is produced from the juices of fruits such as grape, watermelon, apricot, prune, mulberry and sugar beet, all of which contain sugars (Kaya and Belibagli 2002).

Fruit dibis (Pekmez) is a very important food in human nutrition because of it contains high amounts of sugars (65-68\%) especially monosaccharides such as glucose and fructose, minerals and organic acid content, therefore pekmez enhance nutritional properties and shelf life, and provide the desired flavor and colour in cakes and other baked products (Batu, 2005). Ustiin and Tosum, (1997) investigated the composition of 11 pekmez samples. The ranges of average obtained from 11 pekmez samples were as follows: total dry matter $71.9-84.4 \%$, total sugars $49.8-76.8 \%$, invert sugars $16.6-67.9 \%$ and ash $0.41-2.44 \%$, Hydroxy methyl furfural (HMF) content 7.38-166.05 mg/kg, calcium 50.9 - $206.1 \mathrm{mg} / 100 \mathrm{~g}$, sodium $25.4-82.2$ $\mathrm{mg} / 100 \mathrm{~g}$, manganese $11.03-68.3 \mathrm{mg} / 100 \mathrm{~g}$. Phosphorus 0-95.06 mg/100 g, iron 2.62 - $16.30 \mathrm{mg} / 100 \mathrm{~g}$ and zinc $0.18-0.74 \mathrm{mg} / 100 \mathrm{~g}$. The high iron content makes the product a recommended treatment for anemia. In addition, B1 and B2 vitamins add extra value to the product.

Based on these facts, the present study was carried out to produce and evaluate the dibis or concentrate from three varieties of grapes.

\section{MATERIALS AND METHODS}

\section{Materials:}

Three varieties (Thompson seedless \{white\}, Flame seedless and Roumy Ahmer $\{$ red\}) of grape were purchased from the local market in Alex. (Mature grapes). All chemicals and reagents used in the present study were of analytical grade and purchased from El-Gomhouria Co. for trading chemical and medical Appliances, Alexandria, Egypt. While chemicals used in HPLC methods were of HPLC grade and purchased from Sigma Co.

\section{Methods:}

\section{Technological Methods}

\section{Preparation of grape dibis}

The grape dibis was prepared according to the method shown in Figure (1) as cited by (Kaya and Belibagli, 2002) with some modification. All grapes were washed by tap water to remove impurities. Seeds and skin of grapes were removed 
immediately after crushing in order to obtain relatively a clear juice, and then sodium metabisulfite $(0.1 \%)$ was added only to Thompson seedlles grape juice. All grape juices were concentrated using a rotary evaporator (Hahnvapor, Mod No. HS-2005SD, Korea) at $60{ }^{\circ} \mathrm{C}$ up to $70-73 \%$ soluble solids contents. The obtained final dibis was kept in dark bottles in a refrigerator temperature until used.

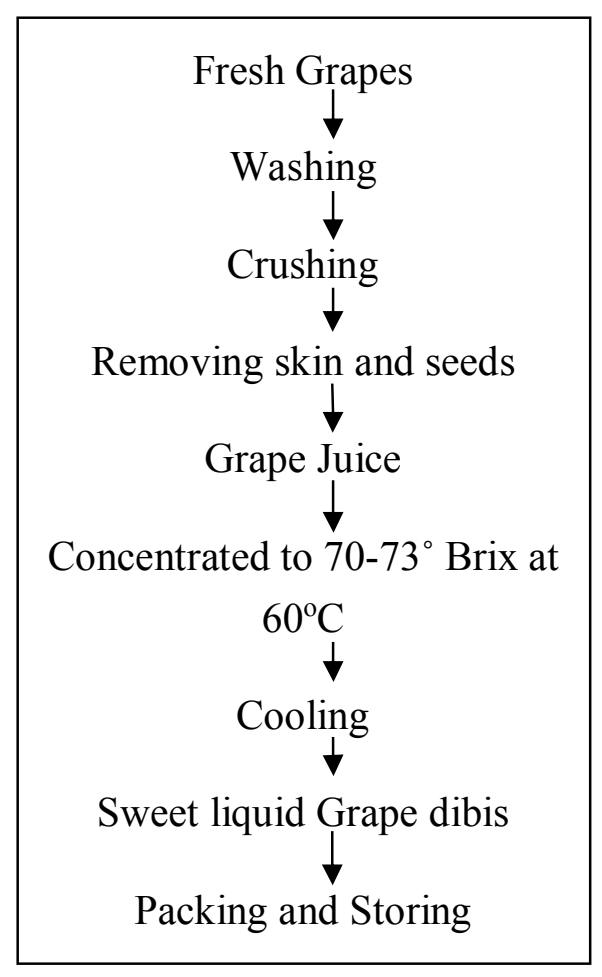

Fig. 1. Steps of production of grape dibis.

\section{Chemical methods}

Total soluble solids (TSS), ash and total acidity were determined according to the methods of AOAC. (2007). pH value was measured by using Beckman pH meter with glass electrode at $25{ }^{\circ} \mathrm{C}$. Total, reducing and non-reducing sugars were determined using Lane- Eynon procedure as stated in the AOAC (2007). The viscosity of all dibis samples were measured at $27 \pm 1^{\circ} \mathrm{C}$ with a Brookfield synchrolcctric mode (H) 3 T71984 viscometer (Cinbas and Yazici, 2008).

\section{Determination of minerals}

Minerals ( $\mathrm{Ca}, \mathrm{Mg}, \mathrm{Fe}, \mathrm{Zn}$ ) were measured using Perkin Elmer Atomic Absorption Spectrophotometer (Model 2380, Japan), On the other hand, $\mathrm{Na}$ and $\mathrm{K}$ were determined using Flame Photometer (Model PE P7, England) as described in the AOAC (2007).

\section{Fractionation of sugars by HPLC.}

The sugar compositions of grape juice and dibis samples were determined as described by (Chinnici et al., 2005). 


\section{Fractionation and Identification of phenolic and flavonoid compounds by HPLC.}

Fractionation and identification of phenolic and flavonoid compounds were determined by HPLC according to the method described by Goupy et al. (1999) and Mattila et al. (2000), respectively.

\section{Determination of vitamin B complex by HPLC.}

Vitamin B complex of grape juice and dibis were determined by HPLC according to the method of Papadoyannis et al. (1997).

\section{Determination of vitamin C by HPLC}

Vitamin C content was analyzed using HPLC described by Romeu-Nadal et al., (2006).

\section{Sensory evaluation}

Colour, taste, odour, texture and overall acceptability from different varieties of grape dibis were assessed by 10 panellists of Food Technol. Lab., Food Technol. Research Inst., Agricultural research Center, of Sabahia, Alexandria, Egypt. The panelists were asked to score the above attributes according to a standard hedonic rating scale from 9 (like) extremely) to 1 (dislike extremely) according to Kramer and Twigg (1973).

\section{Statistical analysis}

The data of the physiochemical and organoleptic properties of the juice and dibis products from different grape varieties were expressed as mean values \pm SD. Statistical analysis was performed using one way analysis of variance (ANOVA) followed by Duncan's Multiple Range Test with $P \geq 0.05$ being considered statistically significant using SAS software program (SAS, 2004).

\section{RESULTS AND DISCUSSION}

Table (1) shows the yield of grape juice and dibis of the grape varieties, it was found that the yield of grape Thompson juice and dibis was higher than the other grape varieties as $3 \mathrm{~kg}$ of Thompson seedless gave $2.780 \mathrm{~kg}$ and $628.17 \mathrm{~g}$ of juice and dibis respectively followed by the yield of juice and dibis of flame seedless and Roumy Ahmer. The high yield of grape juice and dibis of Thompson seedless might be related to the high value of total soluble solids as shown in Table (2).

Table 1. The yield of grape juice and grape dibis of some varieties of grape.

\begin{tabular}{|c|c|c|c|c|}
\hline Grape varieties & $\begin{array}{c}\text { Grape weight } \\
(\mathrm{kg})\end{array}$ & $\begin{array}{c}\text { Juice yield } \\
(\mathrm{kg})\end{array}$ & $\begin{array}{c}\text { Dibis yield } \\
(\mathrm{g})\end{array}$ & Dibis (\%) \\
\hline Thompson seedless & 3 & 2.780 & 628.17 & 22.59 \\
\hline Flame seedless & 3 & 2.530 & 558.44 & 22.07 \\
\hline Roumy Ahmer & 3 & 2.450 & 497.51 & 20.31 \\
\hline
\end{tabular}




\section{Physicochemical properties of grape juice and dibis}

Proximate physicochemical properties of grape juice and dibis are represented in Table (2). Results showed that grape juice of Thompson seedless had the highest total soluble solids (20.16\%) followed by grape juice of Roumy Ahmer and Flame seedless. Titratable acidity ranged from $0.26-0.37$ with a pH 3.90, 3.76 and 4.41 for Thompson seedless, Flame seedless and Roumy Ahmer grape juice respectively, a significant difference was observed in titratable acidity between all samples of grape juice, also significant difference was observed in $\mathrm{pH}$ value between both Thompson seedless and Flame seedless grape juice and the Roumy Ahmer grape juice. From the same Table (2) no significant difference was observed in ash which was $0.45,0.58$ and $\mathbf{0 . 6 4 \%}$ for Thompson seedless, Flame seedless and Roumy Ahmer grape juice respectively. A significant difference was showed in total sugars between Thompson seedless, Flame seedless and Roumy Ahmer grape juice; While reducing sugars recorded $18.82,18.15$ and $17.73 \%$ for the previous samples respectively as shown in Table (2). Nezam eldin and Hanaa (1991) found that Thompson seedless grapes contained $78.0 \%, 20 \%, 0,61 \%, 4.09,18.8 \%, 20.1 \%, 0.29 \%$ and $0.194 \mathrm{mg} / 100 \mathrm{~g}$ for moisture content, TSS, total acidity, pH value, reducing sugar, total sugar, free amino acid and total phenols respectively. On the other hand results of different grape dibis Table (2), showed that a significant difference was recorded in TSS value between both Thompson seedless (73.80\%), Flame seedless (73.93\%) and Roumy Ahmer grape dibis $(71.10 \%)$. Also titratable acidity and ash content of different grape dibis recorded significant differences between them. Grape dibis is a good source of energy and carbohydrates due to its high total sugar contents which were 72.39, 73.0 and $70.62 \%$ while reducing sugars recorded $69.63,71.60$ and $69.93 \%$ for Thompson seedless, Flame seedless and Roumy Ahmer respectively.

\section{Mineral contents}

By measuring the mineral contents of different grape juice and dibis, it could be noticed in Table (3) that all the grape juice contained high concentrations of sodium, potassium, calcium, magnesium, iron and zinc. The aforementioned minerals increased after producing grape dibis from different varieties. Data in Table (3) were not in accordance with that mentioned by Ustiin and Tosum (1997). The variation may be due to the difference in cultivation conditions and practices.

As Pekmez contains high mineral contents and gives energy, it is important in human nutrition. Pekmez contains copper and zinc at definite levels and is especially very rich for iron. As it is known, iron, copper, and zinc are essential minerals for human health. (Demirözü et al., 2002). 
Table 2. Physicochemical properties of grape juice and dibis from different varieties.

\begin{tabular}{|c|c|c|c|c|c|c|c|c|}
\hline \multirow{2}{*}{$\begin{array}{c}\text { Physicochemical } \\
\text { properties }\end{array}$} & \multicolumn{3}{|c|}{ Grape juice } & \multirow[b]{2}{*}{ LSD } & \multicolumn{3}{|c|}{ Grape dibis } & \multirow[b]{2}{*}{ LSD } \\
\hline & $\begin{array}{l}\text { Thompson } \\
\text { seedless }\end{array}$ & Flame seedless & Roumy Ahmer & & Thompson seedless & Flame seedless & Roumy Ahmer & \\
\hline TSS $^{\circ}$ Brix & $20.16^{a} \pm 0.28$ & $19.66^{\mathrm{a}} \pm 0.87$ & $19.83^{\mathrm{a}} \pm 0.29$ & 1.52 & $73.80^{A} \pm 0.50$ & $73.93^{A} \pm 0.577$ & $71.10^{\mathrm{B}} \pm 0.173$ & 1.08 \\
\hline Titratable acidity (\%) & $0.36^{\mathrm{b}} \pm 0.00$ & $0.37^{\mathrm{a}} \pm 0.01$ & $0.26^{c} \pm 0.01$ & 0.02 & $0.42^{\mathrm{C}} \pm 0.01$ & $1.66^{\mathrm{A}} \pm 0.01$ & $1.21^{\mathrm{B}} \pm 0.01$ & 0.02 \\
\hline $\mathrm{pH}$ value & $3.90^{\mathrm{b}} \pm 0.11$ & $3.76^{\mathrm{b}} \pm 0.05$ & $4.41^{\mathrm{a}} \pm 0.07$ & 0.17 & $4.34^{\mathrm{A}} \pm 0.0611$ & $3.66^{B} \pm 0.25$ & $4.65^{A} \pm 0.70$ & 0.32 \\
\hline Ash (\%) & $0.45^{\mathrm{a}} \pm 0.09$ & $0.58^{\mathrm{a}} \pm 0.36$ & $0.64^{\mathrm{a}} \pm 0.085$ & 0.68 & $0.79^{c} \pm 0.04$ & $2.54^{\mathrm{B}} \pm 0.15$ & $4.01^{A} \pm 0.31$ & 0.63 \\
\hline Total sugars (\%) & $19.53^{a} \pm 0.14$ & $18.91^{\mathrm{ab}} \pm 0.53$ & $18.47^{\mathrm{b}} \pm 0.17$ & 0.66 & $72.39^{A} \pm 1.13$ & $73.0^{A} \pm 1.50$ & $70.62^{\mathrm{B}} \pm 1.09$ & 2.64 \\
\hline Reducing sugars (\%) & $18.82^{\mathrm{a}} \pm 0.25$ & $18.15^{\mathrm{b}} \pm 0.11$ & $17.73^{\mathrm{b}} \pm 0.31$ & 0.48 & $69.63^{\mathrm{AB}} \pm 0.61$ & $71.60^{\mathrm{A}} \pm 1.05$ & $69.93^{\mathrm{B}} \pm 1.09$ & 1.88 \\
\hline $\begin{array}{c}\text { Non reducing sugars } \\
(\%)\end{array}$ & $0.71^{\mathrm{a}} \pm 0.108$ & $0.76^{a} \pm 0.42$ & $0.74^{\mathrm{a}} \pm 0.15$ & 0.53 & $2.76^{\mathrm{A}} \pm 1.54$ & $1.31^{\mathrm{AB}} \pm 0.60$ & $0.69^{B} \pm 0.22$ & 1.93 \\
\hline
\end{tabular}

(a-b) Different lowercase superscripts in the same row indicate significant differences $(P<0.05)$ between different grape juice varieties.

(A-B) Different capital superscripts in the same row indicate significant differences $(P<0.05)$ between different grape dibis varieties. 
Table 3. Mineral contents of grape juice and dibis ( $\mathrm{mg} / 100 \mathrm{~g}$ )

\begin{tabular}{|c|c|c|c|c|c|c|c|}
\hline \multirow{4}{*}{ Grape varieties } & $\mathrm{Na}$ & $\mathrm{K}$ & $\mathrm{Ca}$ & $\mathrm{Mg}$ & $\mathrm{Fe}$ & $\mathrm{Zn}$ \\
\hline \multirow{4}{*}{ Juice } & Thampson seedless & 413.53 & 8.42 & 1.83 & 134.46 & 2.69 & 0.34 \\
\cline { 2 - 8 } & Flame seedless & 336.30 & 9.89 & 1.20 & 99.80 & 1.41 & 0.45 \\
\cline { 2 - 8 } & Roumy Ahmer & 687.62 & 14.69 & 1.88 & 217.41 & 2.56 & 0.53 \\
\hline \multirow{3}{*}{ Dibis } & Thompson seedless & 617.86 & 16.61 & 2.81 & 294.70 & 1.99 & 0.97 \\
\cline { 2 - 8 } & Flame seedless & 377.38 & 36.46 & 2.30 & 257.25 & 1.85 & 0.61 \\
\cline { 2 - 8 } & Roumy Ahmer & 802.29 & 59.23 & 2.14 & 335.89 & 2.73 & 0.86 \\
\hline
\end{tabular}

\section{Viscosity measurement.}

The viscosity of different grape dibis varied from 15600 for Roumy Ahmer to $84200 \mathrm{cp}$ for flame seedless as shown in Table (4). The high viscosity of Flame seedless may be related to its high total sugars. By increasing the rpm the viscosity of different grape dibis decreased gradually. Kaya et al., (2008) reported that the pekmez viscosity was affected by soluble solid content and temperature. The change in viscosity was more sensitive to change in temperature at higher solid concentration.

Table 4. Viscosity of dibis from different grape varieties.

\begin{tabular}{|c|c|c|c|}
\hline \multirow{2}{*}{ RPM } & \multicolumn{3}{|c|}{ Viscosity (cp) } \\
\cline { 2 - 4 } & Thampson seedless dibid & Flame seedless dibid & Roumy Ahmer dibid \\
\hline 10 & 70000 & 84200 & 15600 \\
\hline 20 & 48700 & 55400 & 12400 \\
\hline 30 & 39933 & 42800 & 10933 \\
\hline 40 & 33440 & 36200 & 10150 \\
\hline 50 & 30440 & 31680 & 9480 \\
\hline 60 & 29100 & 28000 & 9033 \\
\hline
\end{tabular}

$\mathrm{cp}=$ centipoise

Identification of free sugar contents of grape juice and dibis from different varieties.

In grapes, a large portion of the soluble solid is sugars. Glucose and fructose are the main sugars in the juice. From Table (5) it could be seen that grape juice of Thompson seedless had the highest content of fructose $(10.45 \%)$, followed by Roumy Ahmer (9.14\%) and Flame seedless (7.96\%) while glucose ranged from $8.46 \%$ to $11.57 \%$ for Thompson and Flame seedless respectively. The variation between the percentage of fructose and glucose in different grape juice may be related to the difference in maturity of grape samples. From the consumers' perspective, the organoleptic quality of table grapes depends mainly on the sugar content, organic acid content and the balance between them. In regard to the sugar content, glucose and fructose are present in similar amounts, while sucrose contributes less than $1 \%$ and 
the starch concentration is practically negligible (Conde et al., 2007). Robredo et al. (2011) reported that The ranges of sugars concentrations found in grapes were as follows: fructose, $0.15-8.74(\mathrm{~g} / 100 \mathrm{~g}) ;$ glucose, $0.19-8.71(\mathrm{~g} / 100 \mathrm{~g})$ and sucrose $0.02-0.91(\mathrm{~g} / 100 \mathrm{~g})$.Among sugars, glucose was the most abundant one in early stages and then it decreased until the harvest period, when the amount of fructose and glucose converged to an average of $47 \%$ for each sugar.

After producing grape dibis fructose of Thomson seedless dibis recorded $35.26 \%$ followed by dibis of Flame seedless (33.76\%) and dibis of Roumy Ahmer (31.21\%), also dibis of Roumy Ahmer recorded the highest content of glucose (39.41\%), followed by dibis of Flame and Thompson seedless $(39.24,37.13)$ respectively. Glucose and fructose are the most abundant carbohydrates in grape pekmez, sucrose generally is not found in grape pekmez because it is almost completely hydrolyzed in the boiling stage (Akinci et al., 2004)

Table 5. Fractionation and identification of free sugar content by HPLC of grape juice and dibis from different varieties.

\begin{tabular}{|c|c|c|c|c|c|c|}
\hline \multirow[t]{2}{*}{ Sugar compounds } & \multicolumn{3}{|c|}{$\begin{array}{c}\text { Grape juice } \\
(\%)\end{array}$} & \multicolumn{3}{|c|}{$\begin{array}{c}\text { Grape dibis } \\
(\%)\end{array}$} \\
\hline & $\begin{array}{c}\text { Flame } \\
\text { seedless }\end{array}$ & $\begin{array}{c}\text { Thompson } \\
\text { seedless }\end{array}$ & $\begin{array}{l}\text { Roumy } \\
\text { Ahmer }\end{array}$ & $\begin{array}{c}\text { Flame } \\
\text { seedless }\end{array}$ & $\begin{array}{c}\text { Thompson } \\
\text { seedless }\end{array}$ & $\begin{array}{l}\text { Roumy } \\
\text { Ahmer }\end{array}$ \\
\hline Lactelose & 0 & 0 & 0 & 0 & 0 & 0 \\
\hline L-Rhaminose & 0 & 0 & 0 & 0 & 0 & 0 \\
\hline Inulin & 0.40 & 0.37 & 0.37 & 1.77 & 0.38 & 1.47 \\
\hline Mannose & 0 & 0 & 0 & 0 & 0 & 0 \\
\hline Galacturonic & 0.05 & 0.06 & 0.17 & 0 & 0 & 0 \\
\hline Glucuronic & 0 & 0 & 0 & 0 & 0 & 0 \\
\hline Raffinose & 0 & 0 & 0 & 0 & 0 & 0 \\
\hline Arabinose & 0 & 0 & 0 & 0 & 0 & 0 \\
\hline Xylose & 0 & 0 & 0 & 0 & 0 & 0 \\
\hline Stachyose & 0 & 0 & 0 & 0 & 0 & 0 \\
\hline Sucrose & 0 & 0 & 0 & 0 & 0 & 0 \\
\hline Galactose & 0 & 0 & 0 & 0 & 0 & 0 \\
\hline Lactose & 0 & 0 & 0 & 0 & 0 & 0 \\
\hline Maltose & 0 & 0 & 0 & 0 & 0 & 0 \\
\hline Fructose & 7.96 & 10.45 & 9.14 & 33.76 & 35.26 & 31.21 \\
\hline Glucose & 11.57 & 8.46 & 9.33 & 39.24 & 37.13 & 39.41 \\
\hline D-glucose & 0 & 0 & 0 & 0 & 0 & 0 \\
\hline
\end{tabular}




\section{Fractionation and Identification of vitamin C and vitamin B contents of grapes juice and dibis from different varieties.}

From Table (6) it could be observed that grape juice of Flame seedless had the highest content of vitamin C (Ascorbic acid), thiamin (B1), riboflavin (B2) and niacin (B3) while grape juice of Thompson seedless recorded the highest value of Pyridoxine (B6) and folic acid (B9) compared to the other varieties of grape juice. Concentrated grape juice (dibis) led to a clear increase in all vitamins.

Table 6. Fractionation and Identification of vitamin C and vitamin B contents of grape juice and dibis from different varieties.

\begin{tabular}{|c|c|c|c|c|c|c|c|}
\hline \multicolumn{2}{|c|}{ Grape varieties } & \multicolumn{6}{|c|}{ Vitamins (mg/100g) } \\
\cline { 2 - 8 } & $\begin{array}{c}\text { Ascorbic acid } \\
\text { C }\end{array}$ & $\begin{array}{c}\text { Thiamin } \\
\text { B1 }\end{array}$ & $\begin{array}{c}\text { Riboflavin } \\
\text { B2 }\end{array}$ & $\begin{array}{c}\text { Niacin } \\
\text { B3 }\end{array}$ & $\begin{array}{c}\text { Pyridoxine } \\
\text { B6 }\end{array}$ & $\begin{array}{c}\text { Folic acid } \\
\text { B9 }\end{array}$ \\
\hline \multirow{3}{*}{ juice } & $\begin{array}{c}\text { Thompson } \\
\text { seedless }\end{array}$ & 1.06 & 0.62 & 0.14 & 0.20 & 0.43 & 0.70 \\
\cline { 2 - 8 } & $\begin{array}{c}\text { Flame } \\
\text { seedless }\end{array}$ & 3.22 & 0.72 & 0.16 & 0.24 & 0.28 & 0.52 \\
\cline { 2 - 8 } & $\begin{array}{c}\text { Roumy } \\
\text { Ahmer }\end{array}$ & 0.99 & 0.66 & 0.16 & 0.15 & 0.18 & 0.37 \\
\hline \multirow{2}{*}{ Dibis } & $\begin{array}{c}\text { Thompson } \\
\text { seedless }\end{array}$ & 3.33 & 2.09 & 0.49 & 0.88 & 2.19 & 2.15 \\
\cline { 2 - 8 } & $\begin{array}{c}\text { Flame } \\
\text { seedless }\end{array}$ & 4.39 & 2.23 & 0.51 & 1.42 & 1.07 & 1.38 \\
\cline { 2 - 8 } & $\begin{array}{c}\text { Roumy } \\
\text { Ahmer }\end{array}$ & 3.83 & 2.86 & 0.53 & 0.59 & 2.18 & 1.7 \\
\hline
\end{tabular}

Fractionation and Identification of phenolic compounds by HPLC of grape juice and dibis.

Table (7) shows the quantities of identified phenolic compounds as $\mathrm{mg} / 100 \mathrm{~g}$. As seen in Table (7) pyrogallol was the major phenolic compounds in grape juice of Flame seedless and Thompsom seedless (6.02 and $6.02 \mathrm{mg} / 100 \mathrm{~g})$ it decreased to 4.74 and $5.36 \mathrm{mg} / 100 \mathrm{~g}$ after producing grape dibis respectively, while grape juice of Roumy Ahmer recorded small amounts of pyrogallol $(1.67 \mathrm{mg} / 100 \mathrm{~g})$ that increased to $(5.49 \mathrm{mg} / 100 \mathrm{~g})$ in grape dibis. Results in the same Table (8) indicated that grape juice of Roumy Ahmer had the highest amount of salicylic acid $(7.13 \mathrm{mg} / 100 \mathrm{~g})$ followed by grape juice of Flame seedless and Thompson seedless (4.77 and 4.05 $\mathrm{mg} / 100 \mathrm{~g}$ ) respectively, it decreased to 6.86 and $3.83 \mathrm{mg} / 100 \mathrm{~g}$ in dibis of Roumy Ahmer and Thompson seedless while an increase was observed in Flame seedless dibis $(5.57 \mathrm{mg} / 100 \mathrm{~g})$. Production of grape dibis from different varieties of grape juice led to the increase and decrease in some phenolic compounds. The decrease and loss of phenolic compounds may be related to the oxidation to quinone, also the increases may be related to the non-enzymatic browning reaction (Khames, 2004). 
Table 7. Fractionation and Identification of Phenolic compounds by HPLC of grapes juice and dibis from different varieties.

\begin{tabular}{|c|c|c|c|c|c|c|}
\hline \multirow[b]{2}{*}{$\begin{array}{l}\text { Phenolic compounds } \\
\qquad(\mathrm{mg} / 100 \mathrm{~g})\end{array}$} & \multicolumn{3}{|c|}{ Grape juice } & \multicolumn{3}{|c|}{ Grape dipis } \\
\hline & $\begin{array}{l}\text { Thompson } \\
\text { seedless }\end{array}$ & $\begin{array}{l}\text { Flame } \\
\text { seedless }\end{array}$ & $\begin{array}{l}\text { Roumy } \\
\text { Ahmer }\end{array}$ & $\begin{array}{l}\text { Thompson } \\
\text { seedless }\end{array}$ & $\begin{array}{l}\text { Flame } \\
\text { seedless }\end{array}$ & $\begin{array}{l}\text { Roumy } \\
\text { Ahmer }\end{array}$ \\
\hline Gallic acid & 0.10 & 0.08 & 0.02 & 0.36 & 0.16 & 0.28 \\
\hline 4-Amino-benzoic & 0.24 & 0.13 & 0.08 & 0.23 & 0.10 & 0.23 \\
\hline Pyrogallol & 6.02 & 6.02 & 1.67 & 5.36 & 4.74 & 5.49 \\
\hline Protocatechuic & 0.18 & 0.18 & 0.04 & 0.15 & 0.19 & 0.08 \\
\hline Catechin & 0.72 & 0.23 & 0.19 & 1.95 & 0.26 & 0.89 \\
\hline Chlorogenic & 0.26 & 0.76 & 1.24 & 1.55 & 1.93 & 2.18 \\
\hline Catechol & 1.1 & 0.54 & 0.39 & 0.28 & 0.28 & 0.34 \\
\hline Epi-catechin & 0.25 & 0.62 & 0.29 & 0.24 & 0.26 & 0.27 \\
\hline Caffeine & 0.11 & 1.08 & 0.08 & 0.08 & 0.71 & 0.08 \\
\hline p-OH benzoic & 0.27 & 0.12 & 0.20 & 0.4 & 0.62 & 0.35 \\
\hline Caffeic & 0.09 & 0.01 & 0.03 & 0.12 & 0.03 & 0.07 \\
\hline Vanillic & 0.14 & 0.25 & 0.17 & 0.44 & 0.42 & 0.91 \\
\hline$P$-coumaric & 0.08 & 0.07 & 0.03 & 0.04 & 0.04 & 0.04 \\
\hline Ferulic & 0.08 & 0.08 & 0.02 & 0.06 & 0.06 & 0.06 \\
\hline Isoferulic & 0.04 & 0.09 & 0.02 & 0.05 & 0.14 & 0.6 \\
\hline Resveratrol & 0.11 & 0.05 & 0.42 & 0.12 & 0.12 & 0.20 \\
\hline Ellagic & 0.12 & 0.07 & 0.04 & 0.19 & 0.15 & 0.13 \\
\hline E-vanillic & 0.65 & 0.45 & 0.31 & 2.88 & 2.9 & 1.38 \\
\hline Alpha coumaric & 0.06 & 0.09 & 0.03 & 0.09 & 0.21 & 0.17 \\
\hline Benzoic & 0.39 & 0.22 & 0.29 & 0.50 & 0.33 & 0.57 \\
\hline 3,4,5 Methoxy cinnamic & 0.02 & 0.02 & 0.01 & 0.05 & 0.06 & 0.05 \\
\hline Coumarin & 0.02 & 0.01 & 0.01 & 0.04 & 0.07 & 0.10 \\
\hline Salicylic & 4.05 & 4.77 & 7.13 & 3.83 & 5.57 & 6.86 \\
\hline Cinnamic & 0.03 & 0.01 & 0.01 & 0.01 & 0.03 & 0.03 \\
\hline
\end{tabular}

Fractionation and Identification of flavonoid compounds by HPLC of grape juice and dibis from different varieties.

From data present in Table (8), it can be seen that luteolin, Rutin, Hesperidin, Rosmarinic acid , Quercetrin, Quercetin, Hesperetin, Kaempferol and Naringenin were the major identified Flavonoid compounds. Hesperidin had the highest concentration in Thompson and Flame seedles grape juice (4.65 and $2.15 \mathrm{mg} / 100 \mathrm{~g}$ ) respectively. Also it was noticed that producing dibis from Flame seedless grape juice and Roumy Ahmer led to the increase in the amount of Hesperidin. On the other hand a clear change was also observed in other flavonoids in different grape dibis. Lin and Weng (2006), Khan et al, (2010) reported that the flavonoids have cardioprotective, antioxidant, anti-inflammatory, anti-cancer and antimicrobial properties, and are one of the most potent nutraceuticals in food and phytopharmaceutical products. Therefore, it is paramount to understand the principles of biological activity, bioavailability and metabolism of grape flavonoids in relation to human health. 
Table 8. Fractionation and Identification of flavonoid compounds by HPLC of grapes juice and dibis from different varieties.

\begin{tabular}{|c|c|c|c|c|c|c|}
\hline \multirow{2}{*}{$\begin{array}{l}\text { flavonoid } \\
\text { compounds } \\
\text { ( } \mathrm{mg} / 100 \mathrm{~g})\end{array}$} & \multicolumn{3}{|c|}{ Grape juice } & \multicolumn{3}{|c|}{ Grape dibis } \\
\hline & $\begin{array}{l}\text { Thompson } \\
\text { seedless }\end{array}$ & $\begin{array}{c}\text { Flame } \\
\text { seedless }\end{array}$ & $\begin{array}{l}\text { Roumy } \\
\text { Ahmer }\end{array}$ & $\begin{array}{l}\text { Thompson } \\
\text { seedless }\end{array}$ & $\begin{array}{c}\text { Flame } \\
\text { seedless }\end{array}$ & $\begin{array}{l}\text { Roumy } \\
\text { Ahmer }\end{array}$ \\
\hline Luteolin & 0.12 & 0.08 & 0.14 & 0.28 & 0.17 & 0.30 \\
\hline Rutin & 0.86 & 0.44 & 0.99 & 0.90 & 0.67 & 1.13 \\
\hline Hesperidin & 4.65 & 2.15 & 0.30 & 4.50 & 3.17 & 1.98 \\
\hline Rosmarinic acid & 0.09 & 0.01 & 0.02 & 0.12 & 0.05 & 0.05 \\
\hline Quercitrin & 0.03 & 0.01 & 0.03 & 0.07 & 0.04 & 0.03 \\
\hline Quercetin & 0.02 & 0.01 & 0.02 & 0.1 & 0.03 & 0.04 \\
\hline Hesperetin & 0.10 & 0.07 & 0.10 & 1.89 & 0.91 & 1.15 \\
\hline Kaempferol & 0.02 & 0.82 & 0.06 & 0.85 & 1.22 & 1.59 \\
\hline Naringenin & 0.28 & 0.11 & 0.09 & 0.89 & 0.43 & 0.48 \\
\hline
\end{tabular}

\section{Sensory evaluation of grape dibis:-}

The organoleptic test is generally the final guide of quality from the consumer's point of view (Jimenez et al., 1989). Mean values of sensory evaluation namely colour, taste, odour, texture and overall acceptability of grape dibis are shown in Table (9). Generally, all the products were accepted by the panelists. The description of the overall acceptability by the panelists ranged between extremely acceptable and very much acceptable for all the products. It could be observed that there were no significant differences in the mean values of Thompson seedless grape dibis, Flame seedless grape dibis and Roumy Ahmer grape dibis for taste, odour and texture. It could be clearly noticed that Thompson seedless grape dibis had high scores for all sensory characteristic of grape dibis.

Table 9. Sensory evaluation of grape dibis.

\begin{tabular}{|c|c|c|c|c|c|}
\hline Grape dibis & Colour & Taste & Odour & Texture & $\begin{array}{c}\text { Overall } \\
\text { acceptability }\end{array}$ \\
\hline $\begin{array}{c}\text { Thompson } \\
\text { seedless }\end{array}$ & $8.90^{\mathrm{a}} \pm 0.70$ & $8.81^{\mathrm{a}} \pm 0.87$ & $8.54^{\mathrm{a}} \pm 1.03$ & $8.18^{\mathrm{a}} \pm 0.60$ & $8.90^{\mathrm{a}} \pm 0.83$ \\
\hline \begin{tabular}{c} 
Flame seedless \\
\hline Roumy Ahmer
\end{tabular} & $8.18^{\mathrm{b}} \pm 1.07$ & $8.54^{\mathrm{a}} \pm 0.93$ & $8.27^{\mathrm{a}} \pm 0.90$ & $8.18^{\mathrm{a}} \pm 0.87$ & $8.09^{\mathrm{b}} \pm 0.83$ \\
\hline LSD & 0.71 & $8.18^{\mathrm{a}} \pm 0.87$ & $8.27^{\mathrm{a}} \pm 1.10$ & $7.72^{\mathrm{a}} \pm 1.27$ & $7.81^{\mathrm{b}} \pm 0.98$ \\
\hline
\end{tabular}

(a-b) Different lowercase superscripts in the same column indicate significant differences $(P<0.05)$ 


\section{REFERENCES}

1- Akinci, I., Özdemir, F., Topuz, A., Kabas, Ö. and Çanakci, M. 2004. Some physical and nutritional properties of juniperus drupacea fruits. Journal of Food Engineering, 65:325-331.

2- AOAC. 2007. Official Methods of Analysis of the AOAC. International $18^{\text {th }} \mathrm{Ed}$. Gaithersburg, Maryland, USA.

3- Batu, A. 2005. Production of liquid and white solid pekmez in turkey, Journal of Food quality, 28: 417-427.

4- Chinnici, F., Spinabelli, U., Riponi, C. and Amati, A. 2005. Optimization of the determination of organic acids and sugars in fruit juices by ion-exclusion liquid chromatography. Journal of Food Composition and Analysis, 18: 121-130.

5- Conde, C., Silva, P., Fontes, N., Dias, A.C.P., Tavares, R.M. and Sousa, M.J.. 2007. Biochemical changes throughout grape berry development and fruit and wine quality. Food, 1:1-22.

6- Cinbas A, Yaizic F.2008. Effect of the addition of blueberries on selected physicochemical and sensory properties of yoghurt. Journal of Food Technology and Biotechnology, 46(4), 434-441.

7- Demirözü, B., Sökmen, M., Uçak, A., Yilmaz, H. and Gülderen, S. 2002. Variation of copper, iron, and zinc levels in pekmez products. Bull. Environ. Contam. Toxicol, 69: 330-334.

8- FAO STAT, 2007. FAO Statistical Database. http:/www.fao.org.Accessed 01/06/2011.

9- Goupy, P., Hugues, M., Biovin, P. and Amiot, M. J. 1999. Antioxidant composition and activity of barley (Hordeum yulgare ) and malt extracts and of isolated phenolic compounds. Journal of the Science of Food and Agriculture, 79:16251634.

10- Iyer, M. M., Sacks, G. L. and Zakour, O. I. P.2010. "Impact of harvesting and processing conditions on green leaf volatile development and phenolics in concord grap Juice" Journal of Food Science, 75: 297-304.

11- Jimenez, L.; Ferrer, L. and Paniego, M.L. 1989. Rheology, Composition and Sensory Properties of Pulped Tomatoes. Journal of Engineering, 9: 119-128.

12- Kaya, A. and Belibağli, K. B. 2002. Rheology of solid Gaziantep Pekmez. Journal of Food Engineering, 54: 221-226.

13- Kaya, A., Ko, S. and Gunasekaran, S. 2008.Viscosity and colour change during In situ solidification of grape pekmez. Food BioprocessTechnol. DOI $10.1007 / \mathrm{s} 11947-008-0169-4$. 
14- Khan, N.; Adhami, V.M. and Mukhtar, H. 2010. Apoptosis by dietary agents for prevention and treatment of prostate cancer. Endocrine-Related Cancer, 17:3952.

15- Khames, M.S. 2004. Biochemical and Technological studies on some Natural Phenolic compound as antioxidant. Ph.D. Thesis, Faculty of Agric. Cairo Univ., Egypt.

16- Kramer, A. and Twigg, B.A., 1973. Quality Control for the Food Industry, third ed. AVI Publishing Co., Westport, Conn., London, England, pp. 132-133.

17- Lin, J.K. and Weng, M.S. 2006. Flavonoids as Nutraceuticals. In The Science of Favonoids; Grotewold, E., Ed.; Springer: Berlin, Germany, 213-238.

18- Mato, I.; Luque,S. S. and Huidobro, J. F.2005. "A review of the analytical methods to determine organic acids in grape juices and wines" Food Research International, 38: 1775- 1188.

19- Mattila, P., Astola, J. and Kumpulainen, J. 2000. Determination of flavonoids in plant material by HPLC with diode-array and electro-array detections. Journal of Agricultural and Food Chemistry, 48:5834-5841.

20- Nezam EL-Din, A.M.M. and Hanaa.S.M.A. 1991. Tecnological study on the grape compote preserved in polyethylene. Egypt . Journal of Applied Sciences, 6:173181.

21- Papadoyannis, I. N., Tsioni, G. K. and Samanidou, V. F. 1997. Simultaneous determination of nine water and fat soluble vitamins after SPE separation and RP-HPLC analysis in pharmaceutical preparations and biological fluids. Journal of liquid Chromatography and Related Technologies, 20:3203-3231.

22- Robredo, P.M ., Robledo, p., Manríquez, D., Molina, R., and Bruno G. Defilippi ,B.G. 2011. Characterization of sugars and organic acids in commercial varieties of table grapes, 71:452-458.

23- Romeu-Nadal, M., Castellote, A.I., Astellote A. and Lopez-Sabater M.C. 2006. Rapid high-performance liquid chromatographic method for Vitamin C determination in human milk versus an enzymatic method. Journal of Chromatography B, 830: 41-46.

24- Saito, M., Hosoyama, H., Ariga, T., Kataoka, S. and Yamaji, N. 1998. Antiulcer activity of grape seed extract and procyanidins. Journal of Agricultural and Food Chemistry , 46: 1460-1464.

25- SAS, 2004. SAS Institute Inc. SAS/ETS_ 9.1 User' SAS Institute Inc. 2004. User's Guide. Cary, NC.

26- Ustiin, M.S. and Tosum, I. 1997. Pekmezlerin bilesimi (The composition of pekmez). GIDA, 22: 417-423 (in Turkish). 


\section{انتاج وتقييم الابس من اصناف مختلفة من العنب}

$$
\begin{aligned}
& \text { رضا عبد الحكيم عامر' و عزة كمال الدين عبد الحميدج } \\
& \text { ا ـ قسم بحوث تصنيع الحاصلات البستانية - معهد بحوث تكنولوجيا الاغذية - مركز البحوث } \\
& \text { الزراعية - الاسكندرية - مصر. } \\
& \text { r . قسم بحوث تصنيع الحاصلات البستانية - معهز بحوث تكنولوجيا الاغذية - مركز البحوث }
\end{aligned}
$$

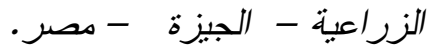

اجريت هذه الدراسة بغرض انتاج دبس العنب ( مركزات عصبر العنب) كمصدر طبيعى للسكر و المركبات النشطة حيويا وذلك من r اصناف من العنب وهى البناتى عديم البذور و الفلام عديم البذور و الرومى الاحمر بالبذور • نم تقدير التركيب الفيزيوكيميائى ، والعناصر المعدنية وذلك

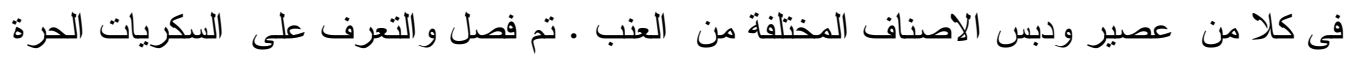
و المركبات الفينولية والفلافونيدات وتقدير فيتامين ج ومجموعة فيتامينات ب وذللك لكل من العصير و الدبس ثم تقييم الخو اص الحسية لدبس العنب ـ. اظهرت النتائج ان المواد الصلبه الذائبة للابس

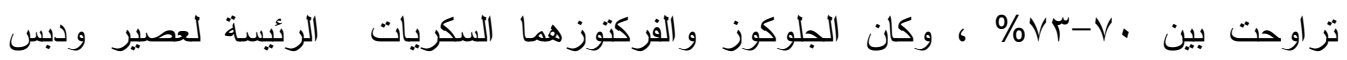
الاصناف المختلفة من العنب. كنلك اظهرت النتائج أن الدبس المصنع من جميع اصناف العنب

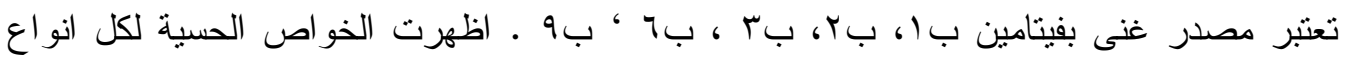

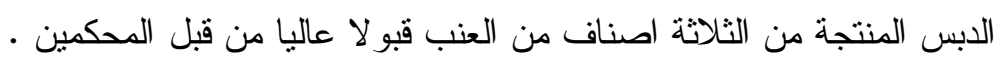

